\title{
Einladung zur Mitgliederversammlung der DRG am Donnerstag, den 30. Mai 2013
}

Zur ordentlichen Mitgliederversammlung der Deutschen Röntgengesellschaft, Gesellschaft für Medizinische Radiologie e.V (DRG), am Donnerstag, den 30. Mai 2013, von 17:15-18:45 Uhr im Congress-Cent-
rum-Hamburg (CCH), lädt der Vorstand die Mitglieder der DRG hiermit herzlich ein.

Zur Teilnahme an der Mitgliederversammlung ist die Vorlage des Mitglieds- ausweises erforderlich. Entsprechend der Satzung der DRG können an der Mitgliederversammlung nur Mitglieder teilnehmen, deren Beitragskonto für 2013 ausgeglichen ist. 